УДК 331.1;338:330.3

DOI: 10.18523/2519-4739.20205.1.124-130

\author{
N. Chala, O. Poplavska
}

\title{
DIGITAL ECONOMY: IMPACT ON THE SOCIO-ECONOMIC TRANSFORMATION IN UKRAINE
}

Having studied the subject matter of Digital economy as a phenomenon, the authors came to the conclusion that it should be considered as a manufacturing and economic system; it is implemented in conditions of redundancy and availability of information, possessing the features of the knowledge economy. Having identified the key role of the state - improving the quality of human resources and increasing the social responsibility of business and society, the authors recommend estimating the impact of Digital economy on the labor market and socio-labor relations in terms of maintaining social security and meeting the development criteria of Economy 4.0. The suggested criteria include economic viability; involvement in the digital economy and knowledge economy; social security; transparency; sustainability. Having identified and estimated the social challenges, the authors noted the most acute, among them, the lack of staff with necessary expertise.

Keywords: digital economy, structure of the digital economy, socio-economic sphere, criteria for the impact of digitalization on the socio-economic transformation, social challenges.

\section{JEL classification: J07, 01:052}

Introduction and the research problem. The digital economy is increasingly influencing the socio-economic development of all countries in the world. Adopting its rules requires rethinking the behavior, level of responsibility of each market actor. One way or another, it will determine how many countries have achieved the Sustainable Development Goals. After all, there are many challenges, especially in the social sphere. Digitalization constantly makes adjustments to the understanding of forms of employment, puts forward requirements for changing approaches to the conclusion of employment relations, a field of unresolved issues regarding pay, organization of the working day, etc. appears. At the macro level, digitalization has encouraged governments to view forms of engagement with business, the public, and to create a transparent field of discussion. At the same time, it created risks of tightening control over the activities of market agents. So today it is clear that only countries that are adapting to the challenges of the digital economy and globalization are capable of witnessing economic growth and improving the quality of life of the population.

Recent publications analysis. Digital economy is considered the driving force of economic growth worldwide. Back in the 60 s of the twentieth century, the United States headed towards digitalization. This decision was based on the research of the
Nobel laureate in Economic Sciences R. Solow (1957). In the article "Technical Change and the Aggregate Production Function", he proved that labor and capital are not the only driving force of economy; thus, he singled out the "residual" (now called "the Solow residual") technological innovation (meaning their driving force of economic development). Technological innovation is such an important driving force of economic development that in 2018, the World Economic Forum has changed the estimation methodology Global Competitiveness Index in order to take the impact of this factor into account (World Economic Forum, 2018). In the estimation of the Bureau of Economic Analysis U.S. Department of Commerce (BEA), the US digital economy grew annually at an average $5.6 \%$ from 2006 to 2016, while real GDP grew at $1.5 \%$ (Barefoot et al., 2018). On a global scale, China is among the leaders of the digital economy. China's digital economy amounted to 30 percent of GDP in 2016 (Tencent, 2017). According to experts, incomings from the digital information technology market in Europe will reach about 1085 billion Euro by 2019 (O'Dea, 2017). The G20 are increasingly orienting their own development vector towards the extension of digital economy and Industry 4.0 technologies.

Unsolved parts of the problem. However, any socio-economic or technological changes that affect 
the society, the labor market, and socio-labor relations, cause debate in the scientific environment, as the states and companies face a number of challenges (socio-economic phenomena are often estimated ambiguously). The negative side of digitization may be the problems of employment and social stratification. Standing G. (2014) points out the emergence of a "dangerous class" of precariates that do not have a stable income and employment (they often work remotely throughout various projects). Autor D. (2010) emphasizes the polarization of the labor market, which finds expression in a decrease of real income, the level of employment of people with low and average qualification.

Florida R. (2012) and Degryse C. (2016), while describing the future of the economy, focus on the problem of unemployment growth due to the takeover of robotics. The authors predict the computerization and automatization of $80 \%$ of jobs in the automotive industry, $70 \%$ - in the production of plastics, $60 \%$ - in the field of security and defense, $45 \%$ - in medicine and health care, $30 \%$ - in the tourism sector in the United States by 2050 . Brussels European and Global Economic Laboratory (BRUEGEL) predicts the computerization and automatization of almost $50 \%$ of professions in several of the most developed European countries, such as Sweden, the UK, France and others in the next 2-3 decades. Countries with active deindustrialization processes, such as Ukraine, Uganda, and Venezuela, need to "leap over" the stage of development in which they are outsiders. Some researchers believe that digitalization entails serious changes in society; consequently, this requires a new social policy (Morrar, Arman \& Mousa, 2017).

Research goal and questions. The purpose of the article is to investigate the essence of the digital economy as a phenomenon and evaluate its impact on the socio-economic situation in Ukraine.

Main findings. The need to understand the vector of processes in the digital economy leads to the study of the essence of this phenomenon. The author's definition: Economy 4.0. is a set of production and economic relations managed by principles of algorithmization and automation, using information and communication links (networks), producing and using digital goods and services, the Internet of things, large amounts of data. Firstly, Economy 4.0. is the basic component of the knowledge economy. One should understand that the focus on digital technologies alone is insufficient; it is vital to use all components of the knowledge economy. Secondly, it is a productive activity of society that has a socio-economic effect on both society as a whole and individual households in particular; it is represented by digital goods and services, technologies, organizational and management decisions. Thirdly, it is a set of production relations managed on the principles of algorithmization and automation, information and communication links (networks).

The authors distinguish the following activities in the digital economy (by cluster):

1. The core (understructure): research aimed at the development of basic knowledge levels, especially in the borderline sciences of biology and physics; physics, chemistry and biology, etc.

2. The basic (defining) level includes programming, design and production of control units, Big Data, creation and implementation of artificial intelligence, electronics;

3. The frame (infrastructure of Economy 4.0.): energetics, education, Internet (the networks themselves), telecommunications, hosting, venture companies, consulting;

4. The digital economy market: Blockchain, Internet of Things, consumers (households and companies, including the sphere of engineering, metallurgy, etc.), social networks, Internet search resources.

A distinctive feature of the Digital economy is developing a symbiosis of man and technology, where most of the formal tasks (functions) are handled by machines through the use of artificial intelligence and robotics. The leading countries of artificial intelligence utilization (mainly developed countries) can get an additional $20-25 \%$ of economic benefits compared to the current situation. For individual employees: a pay rise of specialists with digital and cognitive skills and with expertise in tasks that are hard to automate; however, a reduction of pay for employees completing repetitive tasks. Thus, Digital economy frees people from routine and monotonous work, gets them access to electronic information and provides certain freedom in the organization of labor. At the same time, the role of internal motivation, self-control and personal responsibility for the results of work is increasing; one can also witness individualization of labor (teamwork can be managed remotely).

Therefore, Digital economy is a production and economic system implemented in conditions of redundancy and availability of information and its resources to each market player (increasing risks associated with information security, the need to verify reliability of information, loss of confidence or growth of brand costs) with the necessary interaction between state, corporations (business) and civil society. The authors also believe the level of the Digital 
Table 1. The impact of Digital economy

\begin{tabular}{|c|c|c|}
\hline \multirow{3}{*}{ Criteria for the impact estimation } & \multicolumn{2}{|c|}{ State } \\
\hline & \multicolumn{2}{|c|}{ The impact vector for actors } \\
\hline & + & 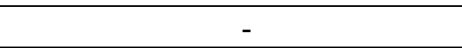 \\
\hline economic feasibility & $\begin{array}{l}\text { economic growth (GDP); } \\
\text { share of middle class no less than } 50 \%\end{array}$ & $\begin{array}{l}\text { retarding GDP growth; incoherence } \\
\text { in the structure of the economy; } \\
\text { reduced investment inflow }\end{array}$ \\
\hline $\begin{array}{l}\text { involvement in the digital economy, } \\
\text { knowledge economy }\end{array}$ & $\begin{array}{l}\text { productive employment; } \\
\text { the share of companies involved in the } \\
\text { digital economy accounts for at least } \\
30 \% \text {; everybody has access to the } \\
\text { achievements of the digital economy }\end{array}$ & $\begin{array}{l}\text { Polarization of unemployment; } \\
\text { severe stratification; } \\
\text { lack of social mobility }\end{array}$ \\
\hline social security & $\begin{array}{l}\text { the quality of human capital is } \\
\text { improving; } \\
\text { the society is stable with no forms of } \\
\text { discrimination }\end{array}$ & $\begin{array}{l}\text { reducing the quality of education; } \\
\text { degrading the creativity of the } \\
\text { economy and the number of } \\
\text { successful research projects; } \\
\text { increased mortality among working } \\
\text { population and children }\end{array}$ \\
\hline transparency & $\begin{array}{l}\text { trust; } \\
\text { fiscal discipline; } \\
\text { rule of law }\end{array}$ & shadow economy \\
\hline stability & $\begin{array}{l}\text { attractive investment climate; } \\
\text { cultural development; } \\
\text { trust }\end{array}$ & $\begin{array}{l}\text { conflicts; } \\
\text { immigration of skilled labor }\end{array}$ \\
\hline
\end{tabular}

Source: by authors

economy development to be affected by the quality of interaction between market players.

Digital economy significantly changes not only production, but also the social sphere. This change finds expression in transforming the society values structure, preferences and behavior of the market actors. Thus, the availability of information and the possibility to process and transfer it in a fast way led to the appearance of remote work and freelancing. Robotics has stimulated the emergence of remote control systems and new requirements for employees (their level of knowledge and expertise in a particular field). The vector of business interests is also changing. For instance, machine learning specialists are the most demanded employees on the labor market today. The socio-economic sphere also witnesses several changes: employment is becoming increasingly unstable; consequently, the percentage of precariat is growing (Standing, 2014); researchers also note the change in employees motives structure and time balance (preferences in the ratio of work and personal time in favor of the latter). However, how should one estimate the depth of these changes?

The authors identified the following criteria for analyzing and evaluating the impact of digitalization and robotization on the socio-economic sphere:

a) economic feasibility - any innovation should lead to economically positive results through increased income of companies, the state, productivity growth, the absence of a negative income balance and social needs disbursements;

b) involvement in the digital economy and knowledge economy - for the economic stability of the state, it is desirable to increase the share of companies involvement, labor in the digital economy sector, while there should be no severe stratification of society; it is vital to maintain social mobility;

c) social security - the economic processes should not contribute to the degradation of the population, aggression, inequality, or other similar phenomena; the level of education should allow people to reproduce healthy offspring capable of research and creative activity;

d) transparency - the financial and management systems should be transparent and clear, leaving no ground for law, rules, or contracts violation;

e) sustainability - the socio-economic sphere should correspond to the needs and demands of market and society in an institutional way, allowing to anticipate future changes and react to them in a timely manner.

According to the authors, Digital economy has a positive $(+)$ impact (improving the interaction of all subsystems, increasing socio-economic indicators, reducing social tension); negative (-) impact (the aggravation of social and economic problems (Table 1). 
on the socio-economic sphere (peer review results)

\begin{tabular}{|c|c|c|c|}
\hline \multicolumn{2}{|c|}{ Company } & \multicolumn{2}{|c|}{ Employee } \\
\hline \multicolumn{4}{|c|}{ The impact vector for actors } \\
\hline+ & - & + & - \\
\hline $\begin{array}{l}\text { profit growth; } \\
\text { growth of labor } \\
\text { productivity, }\end{array}$ & $\begin{array}{l}\text { stagnation, decline as } \\
\text { a result of mismatch } \\
\text { between the organizational } \\
\text { structure and culture, } \\
\text { market requirements and } \\
\text { development stage of the } \\
\text { company }\end{array}$ & stable income & $\begin{array}{l}\text { Decrease of income and } \\
\text { irregularity of its inflow } \\
\text { (the risk of uncertainty); }\end{array}$ \\
\hline $\begin{array}{l}\text { process synchronization; } \\
\text { close cooperation with } \\
\text { scientific/research centers; }\end{array}$ & $\begin{array}{l}\text { lack of coherent and } \\
\text { effective management } \\
\text { systems; } \\
\text { unsatisfactory management } \\
\text { that does not meet the } \\
\text { necessary requirements }\end{array}$ & stable employment & $\begin{array}{l}\text { non-acceptance of } \\
\text { innovations, knowledge; } \\
\text { reluctance to work } \\
\text { (parasitic attitude); } \\
\text { informal employment }\end{array}$ \\
\hline $\begin{array}{l}\text { highly motivated staff; } \\
\text { interaction with educational } \\
\text { centers; } \\
\text { efficient social package }\end{array}$ & $\begin{array}{l}\text { labor dispute; } \\
\text { staff turnover; } \\
\text { substandard internal and } \\
\text { external communications; }\end{array}$ & $\begin{array}{l}\text { harmonization of time and } \\
\text { effort commitment (energy) } \\
\text { to work and personal } \\
\text { development, family }\end{array}$ & $\begin{array}{l}\text { reduced motivation; } \\
\text { frustration; } \\
\text { criminal behavior; } \\
\text { lack of care for the future } \\
\text { generation (lack of value } \\
\text { succession) }\end{array}$ \\
\hline $\begin{array}{l}\text { trust, openness, partnership; } \\
\text { financial discipline }\end{array}$ & $\begin{array}{l}\text { privacy; } \\
\text { the inability of skilled labor } \\
\text { inflow; "shadow economy" }\end{array}$ & $\begin{array}{l}\text { responsibility, self- } \\
\text { discipline }\end{array}$ & $\begin{array}{l}\text { criminal behavior, shadow } \\
\text { patterns; } \\
\text { distrust }\end{array}$ \\
\hline $\begin{array}{l}\text { social responsibility; } \\
\text { availability; } \\
\text { fair evaluation }\end{array}$ & $\begin{array}{l}\text { discrimination; lack of } \\
\text { strategic thinking }\end{array}$ & $\begin{array}{l}\text { gaining culture and } \\
\text { knowledge }\end{array}$ & $\begin{array}{l}\text { degradation; } \\
\text { escaping real life } \\
\text { (psychological disorders) }\end{array}$ \\
\hline
\end{tabular}

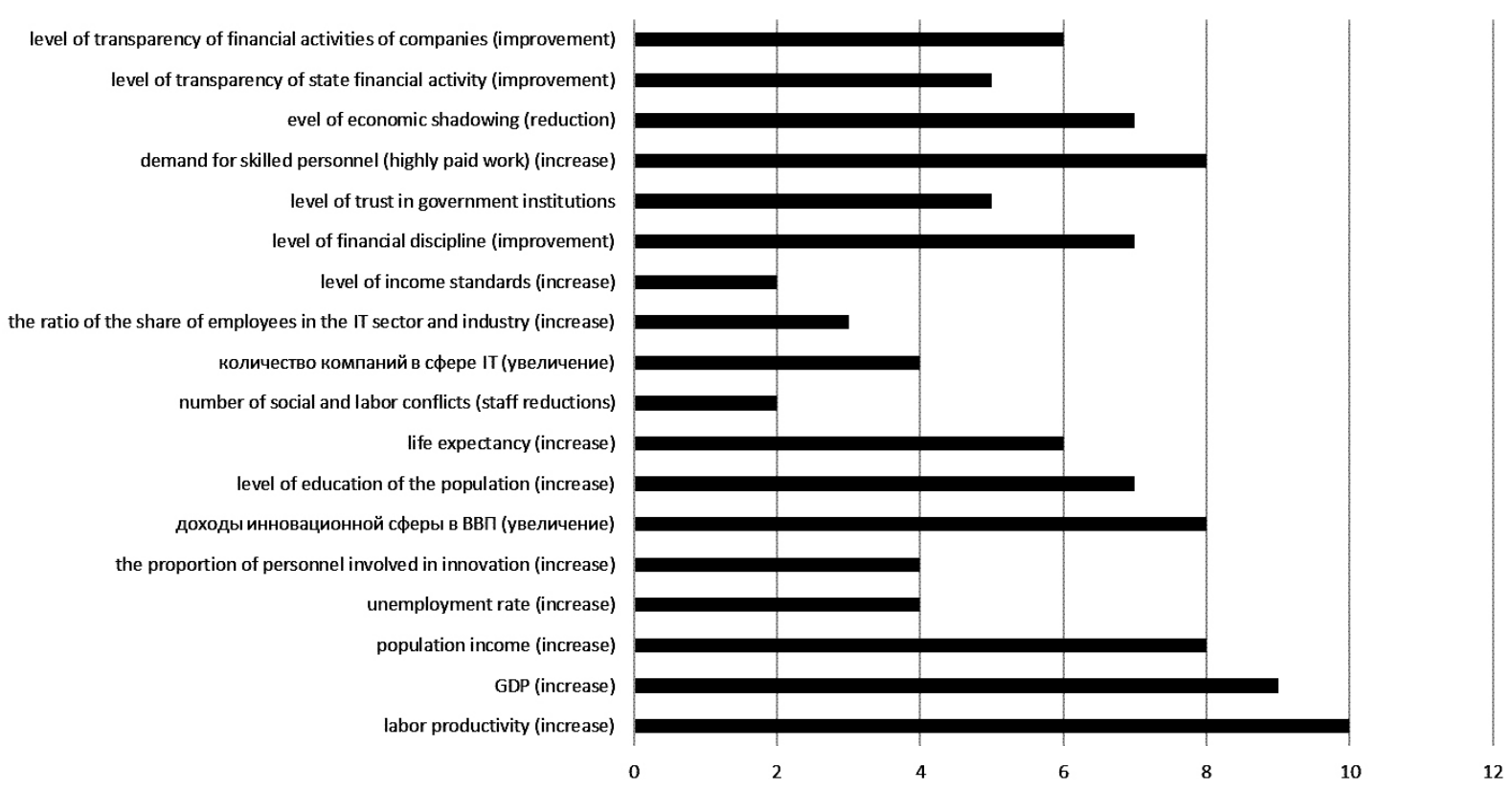

Fig. 1. The ranking indicators of the impact of digitalization on the socio-economic state of Ukraine (average rank) Source: by authors

To determine the power of influence of digitalization on the socio-economic situation in Ukraine as a state, the authors conducted the following study. The method of expert evaluation was used. In doing this, the experts were asked to establish and evaluate (from 1 (the maximum impact) to 10 (its absence)) the impact of digitalization on various indicators of socioeconomic development in the country (based on the sustainable development goals). The following data were obtained (Fig. 1).

Based on this, the authors chose the most important indicators (with a rank of 8-10) - labor productivity, GDP, household income, innovation 
Table 2. Close links between the rating of the country on information and communication technologies implementation and the selected indicators

\begin{tabular}{|c|c|c|c|c|}
\hline Indicator & labor productivity & GDP & $\begin{array}{c}\text { income of the } \\
\text { population }\end{array}$ & $\begin{array}{c}\text { The IT sector labor market } \\
\text { (number of experts) }\end{array}$ \\
\hline Correlation coefficient & 0.884 & 0.836 & 0.756 & 0.855 \\
\hline
\end{tabular}

Source: by authors

income, and the need for highly qualified personnel. In addition, using the correlation calculation method, tightness of connection of each of the selected indicators was estimated (see results in Table 2).

Therefore, the information and communication technologies implementation in Ukraine was proved to have a significant impact on the basic indicators of socio-economic development in the country: labor productivity, demand in IT specialists on the labor market, GDP and income of the population.

However, one should note that actual progress in the digital economy of Ukraine is quite slow in comparison to global indicators. For instance, though we witness a significant increase of demand and job vacancy rate in the IT sphere (those are the most highlycompensated jobs in the country), the income levels are increasing slowly. This means that IT experts are often underestimated (as the employees themselves write on IT forums (Yarovaya, 2019).

Having analyzed the socio-economic indicators (Fig. 2, Fig. 3, Fig. 4) from the standpoint of compliance with these criteria, the authors point out the following problem areas: knowledge relevance; inertia of education; lack of a clear vision on human labor application in the era of artificial intelligence; discrepancy between labor force quality and requirements of the employer.

As we see from Figures 2, 3, 4, the socioeconomic situation in Ukraine has a steady tendency to worsen and the digital economy does not show a positive impact. When these points are not taken into account, the vector of Digital economy is heading in a negative direction.

Thus, social challenges should be considered on several levels (depending on the establishment of decision-making centers): state (macro level), company (micro level) and individual (labor carrier level). The amount of responsibility in each center varies and, as in a hierarchical system, significantly depends on the rules established on the macro level. At the same time, one should not underestimate the individual level, because subjective factors (psychological and physiological features, stability of moral and cultural values) have a real impact on the situation. For instance, the Revolution of Dignity in Ukraine derived from decades of the population's accumulated frustration with the state policy.

The authors identified the following social challenges at the state level:

1) rise of unemployment;

2) fading of the middle class;

3) degradation in the culture of society, escalation of aggressive behavior;

4) lack of an adaptation strategy to the requirements of Economy 4.0;

5) discrepancy between education and the demands of the economy (the inability to provide necessary skills and competencies).

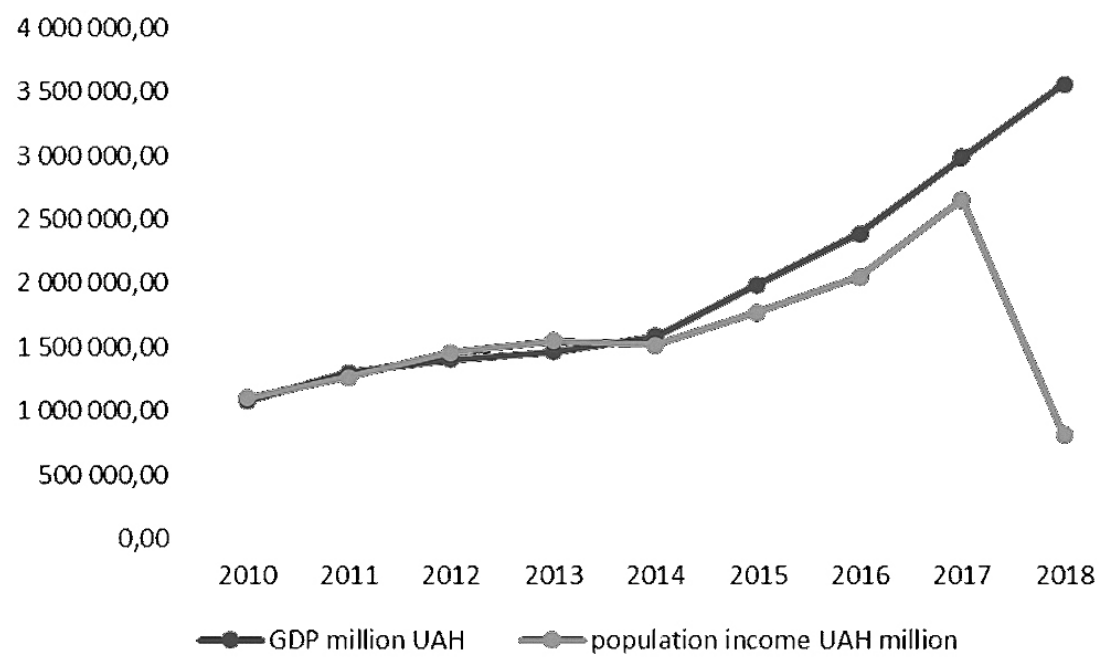

Fig. 2. GDP and income of the Ukrainian population Source: by author based on State Statistics Service of Ukraine data 


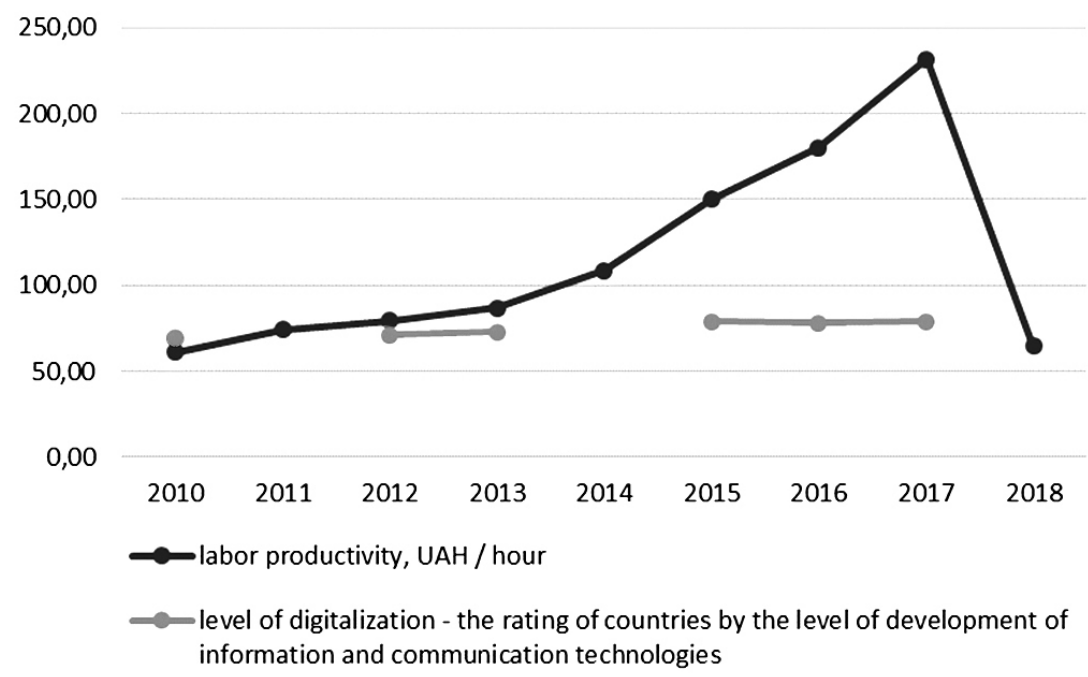

Fig. 3. Labor productivity and Ukraine's rating on ICT development Source: by author based on State Statistics Service of Ukraine data

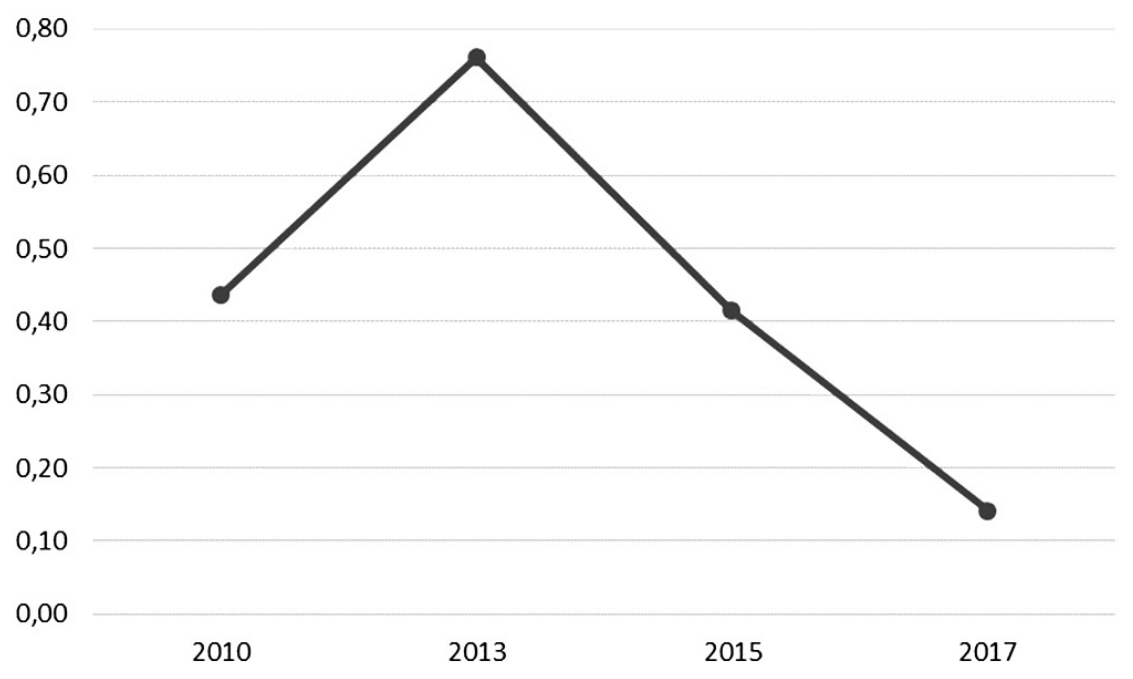

Fig. 4. The integral indicator of social security in Ukraine*

Source: by author by resource State Statistics Service of Ukraine

* The integral indicator of social security is in the range [0-1], where 0 marks a complete absence of conditions for sustainable development and social security, and 1 marks ideal conditions for such development

Conclusions. One way or another, all these challenges are reflected in the system of supply and demand; the lack of labour force to cover the demand is clearly visible (no offers on the market). Thus, the training of personnel that would meet the requirements of the digital economy is the first problem. Furthermore, companies cannot individually solve the problem to the fullest extent; thus, the state needs to coordinate the sphere of education and professional training. The authors also emphasize pressing social challenges for companies - such as lack of personnel with necessary competencies; strengthening social responsibility in the context of dismissing incompetent labor force and its re-qualification; search for effective systems of motivation, including flexible hours and changes in the working schedule; lack of a framework for the use of artificial intelligence (moral and ethical problems); high competition for personnel with innovative ideas. The "conflict" of training programs and the employer's demand for a certain quality of education often emerges. This conflict will progress in the context of the Digital economy because education itself has inertial qualities. Not only because universities do not want to or cannot train highly qualified experts, but because it takes time to do this properly. Moreover, employers do not always anticipate the demand for specific competencies in the future; thus, training programs are modified. As a rule, the employer wants someone who perfectly fits the job 
description; however, such experts are rarely flexible and their knowledge gets out of date within 3-5 years; as a result, employees of this kind are not needed on the labor market.

For the employee, social challenges consist in the need to adapt to innovations and changes associated with digitalization and the 4th industrial revolution; the search for new motives and incentives for development; cultural transformation (new values, lifestyle).

The solution to these challenges lies in education, as all three levels show a correlation between the lack of required competencies and the ability to work productively, to create innovative products.

\section{References}

Autor, D. (2010). The Polarization of Job Opportunities in the US Labor Market: Implications for Employment and Earnings. Community Investments, Fall 2011, 23(2). https://www. researchgate.net/publication/227437438_The_Polarization_of Job_Opportunities_in_the_US_Labor_Market_Implications for_Employment_and_Earnings

Barefoot, K., Curtis, D., Jolliff, W., Nicholson, J. R., \& Omohundro, R. (2018). Defining and Measuring the Digital Economy. $B E A$. https://www.bea.gov/system/files/papers/WP2018-4.pdf

Degryse, C. (2016, February 29). Here Are The New Social Risks Of The Fourth Industrial Revolution. socialeurope.eu. https:// www.socialeurope.eu/here-are-the-new-social-risks-of-thefourth-industrial-revolution

Florida, R. (2012). The Great Reset: How the Post-crash Economy Will Change the Way (M. Nekljudova, Trans.). Moscow: Publishing house "Classic XXI".

Morrar, R., Arman, H., \& Mousa, S. (2017). The Fourth Industrial Revolution (Industry 4.0): A Social Innovation Perspective. Technology Innovation Management Review, 7(11), 12-21. https://timreview.ca/sites/default/files/article_PDF/Morrar_et_ al_TIMReview_November2017.pdf
O’Dea, S. (2017, November 16). Digital economy in Europe Statistics \& Facts. statista.com. https:/www.statista.com/ topics/3887/digital-economy-in-europe/

Solow, R. M. (1957, Aug.). Technical Change and the Aggregate Production Function. The Review of Economics and Statistics, 39(3), 312-320. http://econ22.hosting.paran.com/pub/ Solow(1957).pdf

Standing, G. (2014). The Precariat: The New Dangerous Class (N. Usova, Trans.). Ad Marginem Press.

State Statistics Service of Ukraine. http://www.ukrstat.gov.ua/

Tencent. (2017). China's Digital Transformation: An Analysis from a Socio-economic Perspective. (Presented by Seng Yee Lau at the 5th IMF Statistical Forum). http://www.imf.org/ /media/ Files/Conferences/2017-stats-forum/sy-ppt-for-imf.ashx?la=en

World Economic Forum. (2018). The Global Competitiveness Report 2018. http://reports.weforum.org/global-competitivenessreport-2018/

Yarovaya, M. (2019, February 18). What Ukrainian programmers complained about in 2018: non-transparent wages, outdated equipment, low humidity. ain.ua. https://ain.ua/2019/02/18/nachto-zhalovalis-ukrainskie-programmisty-v-2018-godu/

Чала Н. Д., Поплавська О. М.

\section{ЦИФРОВА ЕКОНОМІКА: ВПЛИВ НА СОЦІАЛЬНО-ЕКОНОМІЧНІ ТРАНСФОРМАЦЇ̈ В УКРАЇНІ}

Вивчивши проблему цифрової економіки як явища, автори дійшли висновку, що ії слід розглядати як виробничу та економічну систему; вона реалізується в умовах надмірності та доступності інформації, володіючи особливостями економіки знань. Визначивши ключову роль держави - поліпшення якості людських ресурсів і підвищення соціальної відповідальності бізнесу та суспільства, автори рекомендують оцінити вплив цифрової економіки на ринок праці та соціально-трудові відносини з погляду підтримки соціального забезпечення задоволення критеріїв розвитку економіки 4.0.

Метою цієї статті $є$ дослідити сутність цифрової економіки як явища та оцінити її вплив на соціально-економічну ситуацію в Україні. 3 огляду на авторське визначення цифрової економіки було виділено критерії для аналізу та оцінки впливу діджиталізації на соціально-економічні трансформації в Україні, а саме: економічної доцільності, соціальної безпеки, прозорості (транспарентності) та сталості.

Для визначення впливу цифровізації на соціально-економічні трансформації в Україні використовували експертне опитування. Експертам було запропоновано обгрунтувати й оцінити (виставити ранг від 1 до 10 , де 1 - максимальний вплив, а 10 - його відсутність) рівень впливу цифровізації на різні показники соціально-економічного розвитку країни.

У результаті дослідження автори розробили рекомендації для ухвалення рішень на рівні уряду, бізнесу, найманого працівника. Визначивши та оцінивши соціальні виклики, автори наголосили на найгострішому серед них - відсутність персоналу з потрібними знаннями.

Ключові слова: цифрова економіка, структура цифрової економіки, соціально-економічна сфера, критерії впливу цифровізації на соціально-економічні трансформації, соціальні виклики.

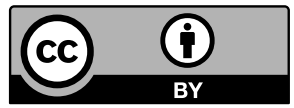

